\title{
Quality in Teacher Education: Evidence from the Universities of Sindh, Pakistan
}

\author{
Zafarullah Sahito \\ School of Applied Educational Science and Teacher Education, Philosophical Faculty, University of Eastern Finland, \\ Joensuu, Finland; \\ Sukkur IBA University, Airport Road, Sukkur, Sindh, Pakistan \\ Pertti Vaisanen \\ School of Applied Educational Science and Teacher Education, Philosophical Faculty, University of Eastern Finland, \\ Joensuu, Finland
}

\begin{abstract}
The quality in teacher education is an emergent topic and area that is discussed throughout the world by teachers, researchers, students, parents and other all concerned and non-concerned stakeholders. Because everyone is connected directly and indirectly to their education system and want to send their children and siblings to those institutions where they get proper, right and authentic education to cater the needs and requirements of the present and future, which is the need of time to live peacefully and prosperously. The qualitative research design with case study approach was employed to collect data and then analysed through thematic-narrative analysis techniques. The study is revolving around the five factors given by UNICEF (2000) such as students and teachers as learners; curriculum/content, material and standards; processes; environments; and outcomes respectively. The findings of this research study would be an excellent addition to the available research findings and the literature of quality education.
\end{abstract}

Index Terms - quality in teacher education, thematic-narrative analysis, students as learners, curriculum, materials and standards, environment and outcomes

\section{INTRODUCTION}

Education is process that works and enables all individuals to achieve their full potentials (UNESCO, 2015b; UNICEF, 2012), which identifies the cognitive development of learners as the key objective (UNESCO, 2005) and emphasizes the role of education in promoting values and attitudes of responsible citizenship (UNESCO, 2005). The intrinsic purpose of education is to engage learners in critical, reflective and metacognitive processes to lead towards the self-discovery and co-creation of knowledge (Sauvé et al., 2005) to understand the complexity of education as embedded in a political, cultural and economic contexts. It is based on a human rights approach (Tikly \& Barrett, 2011) that is a powerful conceptual tool to consider the quality in education depending on the factors of historical and contemporary issues to understand and recognize the different characteristics of children when they entering in to the education system (Hickling-Hudson, 2006). The quality education in the African context embraces both the individual development of the learner and the necessary circumstances to achieve the meaningful learning, which is widely accepted as a significant contribution to development (UNICEF, 2001; Indabawa \& Mpofu, 2006). Education is the basic service and tool offered by governments and other stakeholders through quality process and system to bring economic development in the society (Miller, 2001). Where the quality of education is multi-facetted and articulated differently by various scholars, especially as analysing the internal efficiency of an education system as a fair attempt, wider view and key dimension of the quality education. Whereas, the total eight dimensions of quality education were found in teacher education institutions of Sindh, Pakistan (Sahito \& Vaisanen, 2017c). Whereas, in $21^{\text {st }}$ century, education is considered the fundamental factor and investment for economic, environmental and social development of individuals of the society (Krueger \& Lindhahl, 2001) that converts the human capital in to the successful and strong profitable resources (Tilak, 2002).

The main aim of the study was to investigate the status and proper position of the QE in the light of UNICEF (2000) definition and its list of factors. The perception, experience and the practices of TEs about QE and its factors were recorded with special reference to the five factors of quality given by UNICEF. As the learning and the integration of knowledge, skills and attitudes can be done only through well planned and well managed practices that depend on the proper coordination of different skills to learn and use in their daily life at their working places and environments, that have been learned in school through education and training (Van Merriënboer \& Kirschner, 2007). QE is unique tool to fulfill the needs and requirements of $21^{\text {st }}$ century learners through supporting the learners to transfer the complex cognitive skills to their daily life (Van Merriënboer et al., 2002) to survive properly in this real world through the achievement of the economic developmental goals for quality, peaceful and prosperous life. The input factors consists of the fully equipped physical infrastructure, equipments, tools, library, books, laboratory and playground; students' 
academic achievement, interest and needs; teachers' academic and professional background, socio-economic status, attitude and interest to their profession. Process factors consists of the development of necessary skills, Values and attitudes while the product factors are students' academic progress, and output, interest and efficiency towards learning for the development of their personality. As quality of education is the product of the effective implementation of processes and their results known as outputs, the intended achievement or the desired results may be natural or artificial but must be depending on the continuous inputs, activities and functions (Mishra, 2002).

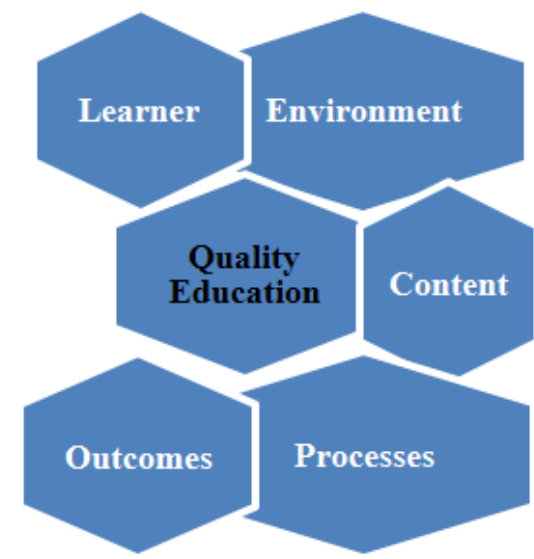

Figure. 1. Factors of Quality Education (UNICEF, 2000)

\section{LITERATURE REVIEW}

\section{A. Quality Education}

The quality in education is a complex term and multifaceted in nature, represented by the different words in different cultural environments in different educational settings such as efficiency, effectiveness, equity and quality synonymously (Adams, 1993). The use of different words for one key word quality provides the unique platform to build a consensus on the basic dimensions of quality education to understand the definition and phenomenon in different perspectives with common understanding. Quality education consists on the participation that revolves around the learners, environments, contents, processes and outcomes. Where learners, are to be healthy, well-nourished and ready to participate; the healthy, safe, protective and gender-sensitive environments could provide adequate resources and facilities; the content, reflected in the curricula and resource materials for the acquisition of basic knowledge and skills; the processes depend on the training of the teachers to use child-centred teaching approaches; while the outcomes encompass knowledge, skills and attitudes for personal and national growth and development.

The quality of education is recognized due to its contribution to national development (Hanushek \& Woessman, 2007), sustainable livelihoods (Bangay \& Blum, 2010) and individual capabilities (Lanzi, 2007) to understand the phenomenon, its clarity (Tawil, Akkari \& Macedo, 2011) and the determining factors. The quality of education is a notion that cannot be captured through any single definition or approach to understand the term or phenomenon in the light of different viewpoints (Motala, 2001) of policy makers, principals, teachers, parents and students, which consist of the common interest in educational outcomes (Scheerens, 2004). It varies by tradition to tradition, such as the economic and humanistic/ behaviorist or progressive tradition (Barrett, Chawla-Duggan, Lowe, Nikel \& Ukpo, 2006) that are opposite to each other. First rejects the prescribed standards and externally defined curricula while second accepts tests and examinations as a major component to understand and examine the quality of learning and the performance of education systems relevant to the socio-cultural circumstances of the nation and learners (UNESCO, 2005). The economic view of education emphasizes on an investment to acquire the knowledge and skills to increase earnings in order to provide long-term benefits to the individuals (Barrett et al., 2006) of the society. Whereas, learning of basic cognitive skills, literacy, numeracy and general knowledge are considered as vital components of quality of education, which are closely connected to the objectives of UNESCO and UNICEF to promote education for humanity, peace and security; purely inspired by a human rights approach (Tawil et al., 2011). As, parents and communities value outcomes like school promotion and employment as a proof of the quality of education concerned with socio-economic development, productivity of workers, economic growth, poverty reduction and stronger integration between national and international knowledge societies to strengthen the social cohesion, cultural diversity and the development of active and responsible citizenship (Tawil et al., 2011).

The factors and indicators of quality are the standardized statements that ensure the comprehensiveness and coverage of the most important relevant domains that reflects the important components of teacher education program (Yackulic $\&$ Noonan, 2001). Whereas, the indicators play the leading role in the performance of the several activities to describe the current position and quantify the pre-determined objectives through providing the continuous feedback to suggest proper strategies for the advancement of the achievement of objectives (European Commission, 2001). The objectives 
may be quantitative, subjective and both mixed such as the learners' engagements, employer satisfaction and competency completion were the three major factors or indicators explored by the Australian quality training framework (AQTF, 2007). These factors are supported by six more factors explored by Thaung (2008) such as the learners, teachers, content, teaching learning processes, learning environments and outcomes. While, the three more factors in the list such as assessment, research and communication were added by Moosa (2006). The programmes and courses; the quality of achievement; students' need assessment and fulfillment; students' learning experiences; students' personal and social development; curricular and vocational guidance and planning for future improvement were the top seven indicators added in the list of quality indicators out of thirty-three about Scottish school system by Her Majesty Inspectorate of Education (HMIE, 2004). Whereas, the sixteen indicators of quality of school education and fifteen indicators of lifelong learning were added in this list found by European Commission (EC, 2001; 2002) respectively. The attainment; success and transition; monitoring of system; and resources and structures were the prime factors out of sixteen, while the main indicators out of fifteen were the skills, competencies and attitudes; access and participation; resources for lifelong learning; and strategies and systems respectively.

The conceptual framework of the study purely consisting of the finding of the quality education of UNICEF (2000), which is comprising of the five factors such as learner, content, process, environments and outcomes. At the same time, this conceptual framework is also working as the guiding and leading framework to conduct study and collect data. However, the concept, perception, engagement, experiences and activites of TEs were limited to the given five factors. It was taken and granted as blessing to welcome the other new factors of quality education, which are said by the interviewees' in their richest statements that are supporting positively and affecting negatively the quality of teacher education.

\section{B. Quality in Higher Education}

The teacher education is a part of higher education, so the system of higher education and its quality can be considered same like other departments and fields of studies. Quality of higher education revolves around who and how students are taught rather than what students learn (Longanecker \& Blanco, 2003). As academic staff is considered as resource and their performance is counted in terms of their individual reputation, quantity and quality of publications and number of courses taught (Koslowski, 2006). However, the administrators define it as a matter of coordination depending on the achievement of numerous institutional goals and obligations. As the quality of higher education was classified in to five aspects such as transcendent; manufacturing-based; product-based; value-based and user-based quality. Whereas the result of reputation of and expertise of academic staff; the service conforms the specifications and is fit to be used in a positive manner as designed for; student learning produced by the curriculum and implemented by academic staff; acceptable performance at an acceptable price; that fulfill the needs, wants and preferences of students respectively (Koslowski, 2006). However, the quality of higher education is defined by four perspectives such as the perception of stakeholders, quantification of elements, course design elements and external standards (Mitchell, 2010). While, the quality of higher education is defined subjectively that determined by the status of peer groups mainly depending on elites rather than the status determined by quality (Bertolin, 2011).

In this regards, most of the studies remained failure to bring a holistic view of the quality in higher that highlights the competition-based view (Akareem \& Hossain, 2012; Ashraf et al., 2009) in order to bring better segmentation and target marketing. Students' qualification and background (Akareem \& Hossain, 2012); individual characteristics such as age, research interests, previous results, perception pattern, family background and income; environmental factors such as social, economic and cultural influences; teacher as ideal or self-image teacher seen by student (Arnon \& Reichel, 2007) are important contributors and play vital roles to understand the perception of education quality. Furthermore, the opportunity to learn during pre-service course, ability to assess student learning, ability to plan curriculum or content units and ability to receive feedback were identified the effective characteristics of teacher education programs (Ingvarson, Beavis \& Kleinhenz, 2007), which measure the students' expectation such as course contents, academic staff and grades (Walker, 2008). Quality can be maintained and enhanced by improving the services provided by different administrative departments such as the registrar office, library, faculty office, rector office, residential units or hostel management, sports departments and health care center (Nadiri, Kandampully \& Hussain, 2009) as tangibles and intangibles services, which have a positive effect on student satisfaction. These all departments have good human resources and management tools, which play important role in developing the teachers, supporting changes in the organisational culture, preparing managers, leaders and academic personnel (Kohont \& Nadoh Bergoc, 2010) to achieve and maintain quality standards.

\section{Quality Reforms in Teacher Education System of Pakistan}

Teacher education plays an essential role to reform and strengthen the education system of any country. The Federal and Provincial Governments have established the teacher education institutions such as Government Colleges for Elementary Teachers Education (GCETs/GCETE), Government Colleges of Education (GCE) and University Departments of Education / IERs in all four provinces of Pakistan to flourish proper and authentic education and training to produce quality teachers for schools, colleges and universities. These teacher educational institutions impart professional education, training and research through various academic programmes from Bachelors to doctoral level. The pre-service teacher education institutions produce teachers every year (Government of Pakistan, 2005) but 
unfortunately their understanding of the content and methodology is low (Government of Pakistan, 1998) that is why the improvement of the quality education was highly focused in new education policy (Government of Pakistan, 2009).

Since last decade, a number of initiatives are being taken to bring quality reforms in teacher education programmes in Pakistan in order to make the measures more focused, cost effective and practically implementable to maintain quality education to bring radical reforms in economic development of the country. As, quality education is directly connected with economic development, which upgrades the quality standards of life of the people in any country. There are many examples of developed countries who upgraded their education system to maintain the quality standards, trainings, research and its commercialization for economic development. The topmost countries who improved the living standards of their people are Finland, Norway, Sweden, Denmark, Germany, France, USA, Canada, UK, Australia, New Zealand, etc. Various agencies are involved for quality assurance in teacher education worldwide but few are the significant in this regards such as national council for teacher education (NCTE) and national assessment and accreditation council (NAAC). Whose main responsibilities are to achieve planned and coordinated development of the teacher education system and to assess, accredit and help the institutions to work continuously to improve the quality of education respectively. There process for assessment and accreditations consists of three stages such as preparation of self-appraisal report by the teacher education institution, self-appraisal report by peers visiting the institution and the final decision of NAAC based on the both reports. For bringing quality reforms in Pakistani teacher education system, a number of initiatives have been taken through public sector bodies especially HEC and its different departments such as Quality Assurance Division (QAD) and National Accreditation Council for Teacher Education (NACTE). The main responsibility of these departments is to identify the significant areas or aspects of quality improvement and measure them scientifically to make more focused and cost effective system. The seven aspects of quality education were identified by NACTE (2009) such as curriculum and instruction; assessment and evaluation system; physical infrastructure, academic facilities and learning resources; human resources; finance and management; research and scholarship; and community links and outreach. For more practicability in mechanism of quality education, the Quality Enhancement Cells (QECs) are established to look after and care through proper mechanism HEC, (2009) depending on qualified human resources, infrastructure, research, environment, curricula and governance (Batool \& Qureshi, 2008).

\section{Methodology}

The qualitative research design with the epistemological and ontological presuppositions (Crotty, 1998) and assumptions of philosophy was used and supported by interpretivism and epistemological constructionism means the reality is manifold and multidimensional and the knowledge is created and a subjective (Creswell, 2009; 2012). The list of characterizing traits to judge the quality to maintain the reliability, validity and usability of the study and protocol (Sparkes \& Smith, 2009, 2014) followed by the steps explored and suggested by Tracy (2010). The thematic-narrative analysis was used to analyse the collected data. As it is a strong technique and has a capacity to capture the correct human and personal dimensions of perception, experience and relationship between individuals and their cultural context (Clandinin \& Connelly, 2000) that focus on the themes and content of stories with appropriate meanings (Polkinghorne, 1995) and converts them in to the real meanings (Riessman, 2008). It is a knowledge creator tool and technique to convert the story in to the social reality (Etherington, 2004) of the own narrator (Etherington, 2000, 2006; Wosket, 1999) or other's clients (Etherington, 2007) for summative analysis (Muylaert, Júnior, Gallo, Neto \& Reis, 2014) consisting of the preparation, initialization, narration, questioning and discussions (Jovchelovich \& Bauer, 2002).

The $(n=40)$ participants were selected through multiple perspectives and sampling of snowball and purposive techniques to collect the in-depth, true and real data. The number of sample was ranging from 1 (one), or 2(two), or 3(three) to 30 or 40, to report properly and comprehensively (Creswell, 2012). In this regards, the four guiding research questions were designed to explore the answers from the narratives of TEs about quality education. The questions were (a). What is the perception of TEs about quality in teacher education? (b). what are the factors of quality in teacher education? (c). what are the agreements of TEs towards the factors of quality given by UNICEF? (d). How TEs support their system to maintain quality at their teacher education institutions?

\section{RESUltS AND Discussions}

The interviews were conducted and the professional stories of TEs were listened carefully on the research topic. The stories of the TEs were found relevant and impressive in order to produce authentic primary data for this study and then analysed the life experiences of interviewees one by one. The sixty-two statements were recorded and coded from all (n $=40$ ) interviews as the narratives of the TEs and then the analysis done with care in relation to the organisational cultures, their vision and mission, available working environment, curriculum, pedagogy, students and their teachers perceptions, the location to serve the community, and the systems the organisation have. In this regard, the detailed results with the main themes, sub-themes, the participants' statements as narratives and their discussions are available here in the following tables from 1 to 5 , with title and theme. 
TABLE. 1

STUDENTS AND TEACHERS AS LEARNERS

\begin{tabular}{|c|c|c|}
\hline Theme & Sub Theme & Participants statements \\
\hline \multirow{4}{*}{$\begin{array}{l}\text { Health and } \\
\text { Psychological } \\
\text { Development }\end{array}$} & $\begin{array}{l}\text { Good health and } \\
\text { nutrition status }\end{array}$ & $\begin{array}{l}\text { Few things were learned from presentations about health and nutrition. There are no suitable } \\
\text { opportunities to learn about good health and nutrition (TE-39). }\end{array}$ \\
\hline & $\begin{array}{l}\text { Learner confidence and } \\
\text { Self-esteem }\end{array}$ & $\begin{array}{l}\text { Students' confidence and self-esteem increased due to working in groups, making their } \\
\text { assignments and presentations. Students' confidence and self-esteem increase the } \\
\text { satisfaction level of their teachers (TE-05). }\end{array}$ \\
\hline & $\begin{array}{l}\text { Regular attendance for } \\
\text { learning }\end{array}$ & $\begin{array}{l}\text { The regularity makes students active and aware about class work and activities to learn well. } \\
\text { Regularity effects positively on their results, skills development and achievement (TE-25). }\end{array}$ \\
\hline & $\begin{array}{l}\text { Early assessment of } \\
\text { disabilities }\end{array}$ & $\begin{array}{l}\text { No early assessment of disabilities is done at any stage completely in educational system } \\
\text { (TE-32). }\end{array}$ \\
\hline \multirow[t]{3}{*}{ Home } & $\begin{array}{l}\text { Home/school/ } \\
\text { community partnership }\end{array}$ & $\begin{array}{l}\text { No suitable and effective policy, programme and activity to maintain partnership between } \\
\text { home, department or school and community to maintain quality education for social, } \\
\text { cultural and economic development (TE-03). }\end{array}$ \\
\hline & $\begin{array}{l}\text { Family support for } \\
\text { learning }\end{array}$ & $\begin{array}{l}\text { Some families or parents support their children physically, financially, socially and } \\
\text { psychologically to learn well. The educated parents and families fulfill their responsibilities } \\
\text { excellently and actively (TE-15). }\end{array}$ \\
\hline & $\begin{array}{l}\text { Positive early } \\
\text { childhood experience }\end{array}$ & $\begin{array}{l}\text { The educated and sensible parents and families take care of their children from their } \\
\text { childhood to teach and train them positively. Students of educated and sensible parents work } \\
\text { well and deal every one socially in their departments (TE-09). }\end{array}$ \\
\hline
\end{tabular}

Learning is important for students and their educational achievement, same way the learning is important for teacher educators. Because learning of teacher educators enhances their thinking, perception and action process and opens new dimensions to them to understand the subject matters, situations, issues and problems of the system, people and society. This understanding creates confidence among them to tackle the problem well and make sensible decision for the benefits of the majority of the stakeholders and the system. This learning process continues until the end of life of the students and teacher educators, known as lifelong learning, enhanced through age and experiences. Learning can be taken placed through attending different courses, working in different groups, assignments and presentation, which increase the confidence, self-esteem and satisfaction of students and teacher educators. In this regards, the regularity of students and TEs plays a pivotal role to create a competitive environment to attract the students to be active members of the classroom to learn well and bring good grades through skill development and knowledge development. Majority of the TE institutions do not have any course, access and facilities to teach their students about good health and nutrition, ethics concerned with day-to-day life (life skills) and citizenship education. There is no effective policy, planning, programme and activity of early assessment of disabilities; partnership between home, department or school and community; focused goals for social, cultural and economic development. However, some educated and sensible parents and families take care and support their children to get higher education especially to become teachers, which is one of favorite profession liked by students and their parents, especially for their female children.

TABLE. 2

CURRICULUM/CONTENT, MATERIAL AND STANDARDS

\begin{tabular}{lll}
\hline Theme & Sub Theme & Participants statements \\
\hline $\begin{array}{l}\text { Curriculum / } \\
\text { Content }\end{array}$ & $\begin{array}{l}\text { Based on defined learning } \\
\text { outcomes }\end{array}$ & $\begin{array}{l}\text { TE curriculum is based on pre-defined learning outcomes concerned with future } \\
\text { development and sustainability to some extent (TE-20). }\end{array}$ \\
\cline { 2 - 3 } & $\begin{array}{l}\text { Non-discriminatory \& student } \\
\text { centered }\end{array}$ & $\begin{array}{l}\text { TE curriculum is non-discriminatory and student centered to most of the extent (TE- } \\
23) .\end{array}$ \\
\cline { 2 - 3 } & Unique local \& national content & $\begin{array}{l}\text { The contents of the subjects of TE represent the local and national content but not } \\
\text { unique in nature (TE-29). }\end{array}$ \\
\cline { 2 - 3 } & $\begin{array}{l}\text { Includes Literacy, Numeracy, } \\
\text { Life skills }\end{array}$ & $\begin{array}{l}\text { The contents of the subjects of TE include literacy, numeracy, pedagogy, practicum } \\
\text { and life skills to some extent (TE-19). }\end{array}$ \\
\cline { 2 - 3 } & $\begin{array}{l}\text { Includes relevant knowledge on } \\
\text { gender equity, HIV/AIDS, } \\
\text { health, nutrition and peace }\end{array}$ & $\begin{array}{l}\text { The contents of the subjects of TE do not fully include the knowledge on gender } \\
\text { equity, HIV/AIDS, health, nutrition and peace (TE-30). }\end{array}$ \\
\hline Materials & $\begin{array}{l}\text { Comprehensible, gender- } \\
\text { sensitive, relevant to schooling }\end{array}$ & $\begin{array}{l}\text { Understandable, clear, logical, relevant and gender sensitive instructional materials } \\
\text { make instructional process effective (TE-33). Need some more good materials to } \\
\text { fulfill the needs and requirements (TE-11). }\end{array}$ \\
& $\begin{array}{l}\text { Standards \& targets for students } \\
\text { The curriculum and contents of the subjects of TE are not fully aligned with } \\
\text { standards and targets for students (TE-37). Still the curriculum and contents need to } \\
\text { be improved and aligned properly for maximum benefits (TE-02). }\end{array}$ \\
\hline Standards & &
\end{tabular}

The new curriculum of TE for Bachelors (four years), MS and Ph.d degrees was designed with the help of foreign experts of USA through Pre-step project of USAID, based on defined learning outcomes concerned with future development and sustainability. As the centralized body of Higher Education Commission (HEC) and USAID (Huma, 2014) initiated the curriculum reforms in teacher education in Pakistan. However, there is a huge need of modification with the passage of time to incorporate it with the nationalization and internationalization needs and requirements. There is also an urgent need to designing the allied materials and course manuals for better understanding and effective results. While, TE curriculum is non-discriminatory and student centered but it is not fully implemented as per the needs and requirements of student-centered system to reach the economic development and sustainability. For the 
required growth and development, TE institutions need highly experts and professional who review the curriculum and contents in order to modify and maintain as per national and international needs and requirement to compete with the system and professionals of developed nations. The main reason of not having experts and professionals in curriculum field is that the people who get degrees in curriculum development, instructions and implementation do not acquire scientific and updated expertise and skills from their department and teachers due to lack of professionals, facilities, opportunities and practices. Even though the Provincial Bureaus of curriculum (BOC) do not play any authentic and leading role in this connection to train the new comers in this field. Because the lack of professionals and experts and effective development and implementation of policies is the main problem that are faced by BOC, which are interpreted by teachers that they influenced their practices and results, leading towards the computable effects (Coburn, 2001; Hill, 2001; Spillane, 2001) and inefficient system.

Generally, the processes at majority of TE institutions found satisfactory not efficient, transparent and meritorious. Especially some of the selected TE are highly competent enough to make their system efficient but majority are selected through different foul means that make the system inefficient through participation in unions and pressure groups. For quality maintenance, the trainings are conducted by HEC for all university faculty members to keep up to date the every one through professional knowledge and lifelong learning. After professional trainings and routine practices, the majority of the TEs learn to take care about their students, their study matters positively depending on gender-sensitive, social enriched and culturally effective with a belief and trust that each student is unique and able to learn well. TEs, heads of the departments and students are the prime participants of feedback mechanism that work for learning and achievement of goals, depending on effective monitoring and assessment system to maintain the conducive and favourable working environment.

In some of the TE institutions the students are given proper attention, special assistance and suitable intervention as per their needs and requirement for better results; time management and utilization skills; language access; utilization of student-centered methods; advance planning through designing of annual and semester wise calendars, time table and events; effective engagements and supervision responsibilities; and administrative support and leadership appreciation to acquire and accelerate the active students' participation for departmental and institutional achievement and success. 
TABLE. 3

PROCESSES

\begin{tabular}{|c|c|c|}
\hline \multirow[b]{2}{*}{ Theme } & \\
\hline & Sub Theme & Participants statements \\
\hline \multirow[t]{7}{*}{ Teachers } & Competence \& school efficiency & $\begin{array}{l}\text { Some of the selected TEs are competent enough to make their system efficient (TE-36). } \\
\text { Majority of TEs are selected through different foul means that make their system } \\
\text { inefficient especially through participation in unions and pressure groups (TE-10). }\end{array}$ \\
\hline & $\begin{array}{l}\text { Ongoing professional learning for } \\
\text { teachers }\end{array}$ & $\begin{array}{l}\text { The professional learning goes on throughout the life of TEs (TE-14). Trainings are } \\
\text { conducted by HEC at different places inside and outside the country for university } \\
\text { teachers (TE-34). }\end{array}$ \\
\hline & $\begin{array}{l}\text { Positive \& gender-sensitive } \\
\text { teacher/students relationship }\end{array}$ & $\begin{array}{l}\text { The majority TEs take care about their students and their matters positively depending } \\
\text { on gender-sensitive, social enriched and culturally effectiveness (TE-31). }\end{array}$ \\
\hline & $\begin{array}{l}\text { Belief that all students can learn \& } \\
\text { commitment to student learning }\end{array}$ & $\begin{array}{l}\text { The most of the TEs trust their students with the belief that everyone is unique creation } \\
\text { of nature and are inculcated with learning qualities (TE-21). }\end{array}$ \\
\hline & $\begin{array}{l}\text { Feedback mechanism that target } \\
\text { learning needs }\end{array}$ & $\begin{array}{l}\text { The feedback mechanism consists of the views of the TEs, heads of the departments and } \\
\text { students that target the learning needs and the achievement of goals (TE-35). }\end{array}$ \\
\hline & $\begin{array}{l}\text { Frequent monitoring and } \\
\text { assessment by teachers that leads to } \\
\text { further learning }\end{array}$ & $\begin{array}{l}\text { Few TEs do monitoring and assessment frequently of their students and systems to help } \\
\text { them for effective and further learning (TE-01). }\end{array}$ \\
\hline & Positive living/ working conditions & $\begin{array}{l}\text { Some TEs try their level best to maintain the conducive and favourable working } \\
\text { conditions at their department through their positive attitude, dealing and relationship } \\
\text { (TE-22). }\end{array}$ \\
\hline \multirow[t]{4}{*}{ Students } & $\begin{array}{l}\text { Intervention \& special assistance } \\
\text { where needed }\end{array}$ & $\begin{array}{l}\text { Students are given proper attention, special assistance and suitable intervention in their } \\
\text { studies in small size classes (TE-18). }\end{array}$ \\
\hline & Time on task & $\begin{array}{l}\text { Students are given suitable time on their tasks as per need, requirement and the nature of } \\
\text { the work (TE-24). Given time on tasks and assignments, inculcate the time management } \\
\text { and utilization skills among students (TE-07). }\end{array}$ \\
\hline & Access to language used at school & $\begin{array}{l}\text { Students and teachers have an access to the language at their department as per policy of } \\
\text { the university (TE-16). }\end{array}$ \\
\hline & $\begin{array}{l}\text { Relevant, student-centered methods } \\
\text { leading to active participation }\end{array}$ & $\begin{array}{l}\text { Some teacher educators use student-centered methods to acquire and accelerate the } \\
\text { active participation of their students (TE-28). }\end{array}$ \\
\hline \multirow[t]{5}{*}{$\begin{array}{l}\text { Supervision } \\
\text { and Support }\end{array}$} & $\begin{array}{l}\text { Adjustment in school hours and } \\
\text { calendars to support students } \\
\text { learning }\end{array}$ & $\begin{array}{l}\text { The annual and semester wise calendars, timetable and events are designed in advance to } \\
\text { facilitate the students learning activities, teachers' engagements and supervision } \\
\text { responsibilities (TE-12). }\end{array}$ \\
\hline & $\begin{array}{l}\text { Administrative support \& } \\
\text { leadership }\end{array}$ & $\begin{array}{l}\text { Administrative support and leadership appreciate the TEs to plan well, design } \\
\text { appropriately and implement properly to get maximum organisational success (TE-13). } \\
\text { Few administrators or heads have good leadership qualities and vision towards the } \\
\text { achievement and success (TE-40). }\end{array}$ \\
\hline & $\begin{array}{l}\text { Using technology to decrease rather } \\
\text { than increase disparities }\end{array}$ & $\begin{array}{l}\text { Some of the TEs use ICT efficiently during their classes (TE-04). TEs make power point } \\
\text { presentations, materials and notes in soft format for their lectures and students (TE-38). }\end{array}$ \\
\hline & $\begin{array}{l}\text { Governments that are supportive of } \\
\text { education system }\end{array}$ & $\begin{array}{l}\text { Governments support education system but unfortunately, their planning, financing and } \\
\text { management is inappropriate, outdated and not effectively implementable (TE-08). The } \\
\text { major issues on government side are corruption, injustice, inequity and inequality, which } \\
\text { make the system incapable to deliver its best (TE-27). }\end{array}$ \\
\hline & $\begin{array}{l}\text { Financial resources for education } \\
\text { system, especially for recurrent } \\
\text { budgets }\end{array}$ & $\begin{array}{l}\text { The financial budget for teacher education departments was not good before } 2010 \text { (TE- } \\
\text { 26). USAID Pre-step project supported a lot to bring radical reforms financially, } \\
\text { physically and resourcefully (TE-17). }\end{array}$ \\
\hline
\end{tabular}

The activities and practices that negatively affect the TE system are less proficiency of TEs and students to use ICT efficiently; inappropriate, ineffective and non-practical government and organisational planning, financing, management and implementation; corruption, injustice, inequity and inequality, which create the system incapable to deliver its best in order to bring radical reforms financially, physically and resourcefully for economic development of the nation. 
TABLE. 4

ENVIRONMENTS

\begin{tabular}{lll}
\hline Theme & Sub Theme & Participants statements \\
\hline Physical Elements & $\begin{array}{l}\text { Access to quality school facilities } \\
\text { including water and sanitation }\end{array}$ & $\begin{array}{l}\text { The physical facilities are quite ok (TE-06). Newly constructed } \\
\text { building, furniture, drinking water and sanitation are available (TE-32). }\end{array}$ \\
\hline Class size & $\begin{array}{l}\text { The classes are fully loaded with more than 50 students and some are } \\
\text { even more than 100 (TE-11). }\end{array}$ \\
\hline $\begin{array}{l}\text { Psychosocial } \\
\text { Elements }\end{array}$ & $\begin{array}{l}\text { Peaceful, safe environment especially } \\
\text { for girls }\end{array}$ & $\begin{array}{l}\text { The peaceful and safe environment is the priority of TE departments for } \\
\text { all students especially for girls (TE-14). Sexual harassment is reported } \\
\text { in few TE institutions (TE-24). }\end{array}$ \\
\cline { 2 - 3 } & $\begin{array}{l}\text { Effective school discipline, health and } \\
\text { nutrition policies }\end{array}$ & $\begin{array}{l}\text { The discipline is quite effective (TE-16). Health and nutrition policies } \\
\text { are outdated and are not implemented appropriately (TE-40). }\end{array}$ \\
\cline { 2 - 4 } & $\begin{array}{l}\text { Inclusive environments } \\
\text { Students from all cultures are given right and freedom to express their } \\
\text { own opinions and points of view to fully participate in teaching, } \\
\text { learning and social activities (TE-08). Few students and teachers are } \\
\text { targeted by their seniors to abuse, harass and unfairly criticized (TE-17). } \\
\text { Students are used to work as spy of the heads of the departments and } \\
\text { organisations to report every activity done in classrooms (TE-06). }\end{array}$ \\
& $\begin{array}{l}\text { Most of the teacher education departments have no health service } \\
\text { facilities especially for emergencies and first aids (TE-39). Most of the } \\
\text { teacher education departments have no sick room, nurse and doctor to } \\
\text { deal with emergencies (TE-09). }\end{array}$ \\
\hline Service Delivery &
\end{tabular}

The environment of most of the TE institutions are quite good with especial reference to the physical facilities such as building, furniture, drinking water and sanitation, which are constructed in collaboration of USAID and HEC. Including the available facilities, there is separate girls' common rooms at TE institutions, which make the environment peaceful and the discipline quite effective for all students especially for girls. Students are given opportunities to express and share their views, ask questions from their teachers and fully participate in teaching-learning and social activities process actively.

The majority of the classes are admitted 50 to 100 students, which effect negatively their learning and participation. The health and nutrition policies are outdated and are not implemented properly and authentically for the benefits of students to deal with any emergencies. Even though, there is no sick room, nurse and doctor at any TE institute to attend any student patient in emergency. Some students and teachers are targeted, unfairly criticized and sexually harassed by their senior teachers, reported at few TE institutions of the large institutions and universities. Some heads use their students as spy of the class and departments to inform about every activity done in classrooms.

Outcomes of quality education are directly concerned with the quality products, which are students' knowledge, awareness, ability to do something and learning for life needs and requirements known as achievement in literacy, numeracy and life skills. Some subjects have few topics about health, nourishment, anti-exploitation and anti-violence. Class and organisational discipline inculcate respect for diversity, which teach them the high practice of quality through different courses that make them obedient, practical and different from others. They learn their content quite well and try to acquire good grades in literacy, numeracy and life skills, but majority of them learn their contents satisfactorily to pass their courses and get degree. These types of students learned the basics and they need some more practice, supervision, opportunity and time to get mastery that can be acquired and achieved in their professional life later.

No orientation is arranged for students to aware them about their rights, responsibilities and duties, issues in health, nourishment, exploitation and violence, and participation in decision-making process. As, there is no written document available in any institution in which the students' rights, responsibilities and duties are described as principles, rules and laws. In few TE institutions, students are given welcome and farewell parties to introduce them with their teachers and senior students and the visits of different offices and spaces are arranged for them to know how to deal with the day-today life matters in campus. 
TABLE. 5

OUTCOMES

\begin{tabular}{lll}
\hline Theme & Sub Theme & Participants statements \\
\hline $\begin{array}{l}\text { Students' } \\
\text { knowledge } \\
\text { and } \\
\text { awareness }\end{array}$ & $\begin{array}{l}\text { Students' awareness about their rights, } \\
\text { responsibilities, duties, and opportunities. }\end{array}$ & $\begin{array}{l}\text { No orientation is given to students about their rights, responsibilities and } \\
\text { duties (TE-29). No written document is available in any institution (TE-02). }\end{array}$ \\
\cline { 2 - 3 } & $\begin{array}{l}\text { Students' awareness about labor laws and } \\
\text { practices for job hunting. }\end{array}$ & $\begin{array}{l}\text { No orientation is given to students about their rights, responsibilities and } \\
\text { duties (TE-36). No written document is available in any institution (TE-21). }\end{array}$ \\
\cline { 2 - 3 } & $\begin{array}{l}\text { Students' awareness and practice about } \\
\text { health issues and precautions, } \\
\text { nourishment, and free from exploitation } \\
\text { and violence. }\end{array}$ & $\begin{array}{l}\text { Not properly focused to provide any awareness about the issues of health, } \\
\text { nourishment, exploitation and violence (TE-18). Few subjects have few } \\
\text { clicks and TEs use to discuss sometimes (TE-12). }\end{array}$ \\
\hline $\begin{array}{l}\text { Students' } \\
\text { ability }\end{array}$ & $\begin{array}{l}\text { Students' ability to participate in decision } \\
\text { making that effect their lives through } \\
\text { evolving capacities. }\end{array}$ & $\begin{array}{l}\text { No awareness and opportunities to know and participate in decision- } \\
\text { making process (TE-38). }\end{array}$ \\
\cline { 2 - 3 } & $\begin{array}{l}\text { Students ability to respect diversity, } \\
\text { practice quality and resolve difference } \\
\text { without violence. }\end{array}$ & $\begin{array}{l}\text { Due to class and organisational discipline students respect diversity (TE- } \\
\text { 27). Due to requirement of different courses students learnt to practice } \\
\text { quality that make them different from others (TE-26). }\end{array}$ \\
\hline $\begin{array}{l}\text { Learning for } \\
\text { life needs and } \\
\text { requirements }\end{array}$ & $\begin{array}{l}\text { Students' knowledge and achievement in } \\
\text { literacy, numeracy and life skills }\end{array}$ & $\begin{array}{l}\text { Some students learn their content quite well and try to achieve good grades } \\
\text { in literacy, numeracy and life skills (TE-25). Majority of the students learn } \\
\text { their contents satisfactorily and they need some more practice and time to } \\
\text { get mastery that can be possible in their professional life (TE-20). }\end{array}$ \\
\end{tabular}

Learning is important for students and teacher educators too that directs, improves and enhances the thinking, perception and action process of the all concerned stakeholders. It opens new dimensions to them in order to understand the subject matters, situations, issues and problems of their system, people and society in order to plan well for their prosperous future economic development through confidence development. In this regards, the TE institutions have to take responsibility to introduce new courses in order to cater the needs and requirements of the students to learn latest life skills and citizenship education through effective policy and planning. Furthermore, the educated and sensible parents and families can be involved to help educational institutions to take care and support their children to get higher education especially to become teachers with curiosity of teaching as favorite profession. Curriculum/Content, material and standards are the important things that play a vital role in quality education. Because curriculum and its implementation is cyclic and re-cyclic process that needs the modification with the passage of time in order to meet the national and international needs and requirements. In this regards, the allied materials and course manuals are to be design for orientations, trainings, proper guidelines and implementation of the curriculum. For better understanding and effective results, the need of highly experts and experienced professional would be needed to review the curriculum and contents in order to modify and maintain them as per national and international requirement. For more progressive results, the processes should be efficient, transparent and meritorious that purely depending on the selection of the highly competent enough TEs, who make, manage and maintain their system efficient, effective and results oriented. In this regards, the competent students or prospective teachers (PTs) would be given proper attention, special assistance and suitable intervention to prepare and trained them for future endeavors to cater the needs and requirements of the TE institutions for better results. The fourth factor is the environments, which are the most important and consists of the physical facilities and working relations that make the human and material resources peaceful and disciplined to achieve the required results through making students active and classrooms as laboratory of sharing and learning knowledge. The last factor is outcomes that are directly concerned with the quality products concerned with students' knowledge, awareness, ability to do something and learning for life needs and requirements such as achievement in literacy, numeracy and life skills. Outcomes cannot be achieved expect the class and organisational discipline that inculcates respect for diversity, obedience, practicability and practices to grip the pedagogical and andragogical skills. For the achievement of every outcome, the orientation should be arranged for all stakeholders to share the concept and further planning to work well on the plan for better achievement as it is said better understanding for better achievements.

The advancement in education is a continuous process that brings change and innovation in curriculum, methodology and evaluation, which takes place in curriculum at two levels such as the course contents and the training of the concerned teachers (Tunio \& Aziz, 2012). The four factors of effectiveness and quality such as intervention, contextualizing, sustaining and ignition can be best suited to bring advancement. As, trained teachers and TEs perform five activities on daily basis to maintain the quality at their departments such as planning, organizing, leading, controlling and adopting activites (Sahito \& Vaisanen, 2017b). These activities are connected with the curriculum and its implementation. Whereas, some further activites are performing by TEs such as making and reviewing the syllabus; preparing subject manuals; lesson planning and completing the material development; making and sharing the assignment guidelines and instructions; assessing students' tests or examinations; timely counseling and guidance activities; timely feedback for constructive progress; appreciating, motivating and supporting the students to participate in co-curricular activities (Sahito \& Vaisanen, 2017a). In this regards, the best example is the Finnish education system that focus and approach to fulfill the needs and demands of the increasing standards through putting a lot of trust in teachers, teacher educators and local education authorities in order to deliver their best (Malinena, Vaisanen, \& Savolainena, 2012), which is lacking in Pakistani education system. The transparent and meritorious methods, systems 
and ways of selection are needed to recruit the competent people for teaching and non-teaching positions (Sahito \& Vaisanen, 2016) in order to maintain and manage the quality education at all levels.

\section{CONCLUSION}

We conclude based on the collected data and its analysis that the all five factors are quite ok for maintaining quality in TE institutions in Sindh, Pakistan. However, the four other factors should be included among them broadly on urgent basis such as the recruitment and initial preparation of teachers and TEs; teacher development, support, career and employment conditions; teacher evaluation and compensation; teacher participation and engagement in policy designing and drafting, decision making and educational reforms. These four more factors would be helpful to support the system to achieve the aims and objectives of quality education such as learning needs; healthy and free from exploitation, violence and labour; awareness of rights and opportunities; able to participate in decisions that affect the lives of all stakeholders in accordance; and able to respect the diversity, effective practices for quality achievements and resolve differences without violence. Because, the quality depends on the quality of the instruments (content) and process factors through research-based framework depending on self-evaluation (SE) comprised of the both content and process factors that allows to evaluate the quality of self-evaluation (Van der Bij, Geijsel \& Ten Dam, 2016). Furthermore, for the quality education, it is necessary to meet the content and process conditions of self-evaluations, the governance, and supervision issues at the level of schoolboards or top-level management depending on a balance between internal and external supervision and the role of school managers in the process of self-evaluation (Van der Bij, Geijsel \& Ten Dam, 2016). In this regards, the internal supervisors can serve excellently than the external ones to maintain mediators between the government, management, the participants, and the environment to promote the learning and the working capacity of an organisation (Schillemans, 2011). Because the quality assessment and consequent supervision can bring the high level of educational quality (Inspectorate of Education, 2015) in any educational institutions. The realization about the high quality of education was made due to the attention paid by the external pressures and the internal desire of institutions (Hooge \& Honingh, 2014) depending on the proper monitoring and the performance promoting system that stimulate the quality development (Gaertner, 2013) in the educational organisations. These all steps towards the quality education can be taken through the decentralisation and the distribution and due involvement in the powers dedication and sharing like the most of the policies of many Western national governments have been given to educational institutions to enjoy their greater autonomy (OECD 2012; Ranson, 2011). Furthermore, the quality education is connected with the pragmatic goals that explained as all the children have access to a quality education; their teachers are trained in innovative ways; teaching learning process depends on the child-friendly methods; and the learning is relevant and connected to the community and society (UNICEF, 2012).

\section{REFERENCES}

[1] Akareem, H. S., \& Hossain, S. S. (2016). Determinants of education quality: what makes students' perception different? Open Review of Educational Research, 3(1), 52-67.

[2] Adams, D. (1993). Defining Educational Quality. Arlington, VA: Institute for International Research and University of Pittsburgh, USAID, Improving Educational Quality Project.

[3] Arnon, S., \& Reichel, N. (2007). Who is the ideal teacher? Am I? Similarity and difference in perception of students of education regarding the qualities of a good teacher and of their own qualities as teachers. Teachers and Teaching: Theory and Practice, 13(5), 441-464.

[4] Ashraf, M.A., Ibrahim, Y., \& Joarder, M.H. (2009). Quality education management at private universities in Bangladesh: An exploratory study. Jurnal Pendidik dan Pendidikan, 24, 17-32.

[5] Australian Quality Training Framework. (2007). Quality indicators overview. Australia. AQTF.

[6] Bangay, C., \& Blum, N. (2010). Education Responses to Climate Change and Quality: Two Parts of the Same Agenda? International Journal of Educational Development, 30(4), 335-350.

[7] Barrett, M. A., Chawla-Duggan, R., Lowe, J., Nikel, J., \& Ukpo, E. (2006). The Concept of Quality in Education: A Review of the International Literature on the Concept of Quality in Education, Working paper no. 3, University of Bristol and University of Bath, UK.

[8] Batool, Z. \& Qureshi, R.H. (2008). Quality assurance manual for higher education in Pakistan. Islamabad: Higher Education Commission.

[9] Bertolin, J.C.G. (2011). The quasi-markets in higher education: From the improbable perfectly competitive markets to the unavoidable state regulation. Educação e Pesquisa, 37(2), 237-248.

[10] Clandinin, D.J., \& Connelly, F.M. (2000). Narrative Inquiry: Experience and story in qualitative research. Published by JosseyBoss, John Wiley \& Sons, Inc., San Francisco.

[11] Coburn, C. (2001). Collective sense making about reading: How teachers mediate reading policy in their professional communities. Educational Evaluation and Policy Analysis, 23(2), 145-170.

[12] Creswell, J. W. (2009). Research design: Qualitative, quantitative and mixed methods approaches, $3^{\text {rd }}$ (ed.). London, England: Sage Publications.

[13] Creswell, J. W. (2012). Educational research: planning, conducting, and evaluating quantitative \& qualitative research, $4^{\text {th }}$ (ed.). Pearson Education, Inc., Boston, USA.

[14] Crotty, M. (1998). The foundations of social research: Meaning and perspective in the research process. London, England: Sage Publications. 
[15] Dilshad, M., \& Iqbal, H.M. (2010). Quality Indicators in Teacher Education Programmes. Pakistan Journal of Social Sciences (PJSS), 30(2), 401-411.

[16] Etherington, K. (2000). Narrative approaches to working with adult male survivors of childhood sexual abuse. London: Jessica Kingsley.

[17] Etherington, K. (2004). Becoming a reflexive researcher: using ourselves in research. London: Jessica Kingsley.

[18] Etherington, K. (2006). Chicken or egg? An exploration of the relationships between physical and psychological symptoms with a woman diagnosed with Tourette's syndrome. In Counseling and Psychotherapy Research, 6(2), 138-146.

[19] Etherington, K. (2007). Ethical research in reflexive relationships. Qualitative Inquiry, 13 (50), 599-616.

[20] European Commission. (2001). European report on quality of school education. Luxembourg: Directorate-General of Education and Culture.

[21] European Commission. (2002). European report on quality indicators of lifelong learning. Brussels: Directorate-General of Education and Culture.

[22] Gaertner, H. (2013). Praxis und erhältnis interner und externer Evaluation im Schulsystem im internationalen Vergleich [Practice and Relationship intern and extern evaluation in school system, an international comparison]. Zeitschrift für Erziehungswissenschaft, 16, 693-712.

[23] Government of Pakistan. (1998). National education policy 1998-2010. Islamabad: Ministry of Education.

[24] Government of Pakistan. (2005). National education census 2005. Islamabad: Ministry of Education. Academy of Educational Planning and Management and Statistics Division, Federal Bureau of Statistics.

[25] Government of Pakistan. (2009). National education policy 2009. Islamabad: Ministry of Education.

[26] HEC. (2009). Annual report 2007-08. Islamabad: Higher Education Commission.

[27] Her Majesty Inspectorate of Education. (2004). Quality indicators in enterprise in education. Scotland: HMIE.

[28] Hanushek, E. A., \& Woessman, L. (2007). The Role of Education Quality in Economic Growth. Working Paper 4122, World Bank, Washington, DC.

[29] Hickling-Hudson, A. (2006). Cultural Complexity, Postcolonial Perspectives, and Educational Change: Challenges for Comparative Educators. International Review of Education, 52(1), 201-218.

[30] Hill, H. (2001). Policy is not enough: Language and the interpretation of state standards. American Educational Research Journal, 38(2), 289-318.

[31] Hooge, E. H., \& Honingh, M. E. (2014). Are school boards aware of the educational quality of their schools? Educational Management Administration \& Leadership, 42(4), 139-154.

[32] Huma, A. (2014). Hopes and Fears: Teacher Educators' Voices in Curriculum Reform. International Journal of Humanities and Social Science, 4(8), 182-195.

[33] Indabawa, S. \& Mpofu, S. (2006) The Social Context of Adult Learning in Africa. Hamburg, Germany: UNESCO Institute for Education, Published in June 2008 in Adult Education Quarterly, 58(4), 342-346.

[34] Ingvarson, L., Beavis, A., \& Kleinhenz, E. (2007). Factors affecting the impact of teacher education programmes on teacher preparedness: Implications for accreditation policy 1. European Journal of Teacher Education, 30(4), 351-381.

[35] Inspectorate of Education (2015). Voorlopig ontwerp toezicht 2016. [Preliminary design supervision 2016]. Utrecht: Inspectie van het onderwijs.

[36] Jovchelovich, S., \& Bauer, M.W. (2002). Entrevista Narrativa. In: Bauer MW, Gaskell G. Pesquisa qualitativa com texto, imagem e som: um-manual prático. Petrópolis: Vozes; p. 90-113.

[37] Kohont, A., \& Nadoh Bergoc, J. (2010). On the Way into the Bologna, reform a consideration of the quality and the role of human resource management in higher education system. Quality of Higher Education, 7, 12-36.

[38] Koslowski III, F.A. (2006). Quality and assessment in context: A brief review. Quality Assurance in Education, 14(3), $277-288$.

[39] Krueger, B. A., \& Lindhahl, M. (2001). Education for growth: why and for whom? Journal of Economic Literature, 39, 11011136.

[40] Lanzi, D. (2007). Capabilities, human capital and education. Journal of Socio-Economics, 36(3), 424-435.

[41] Longanecker, D. A., \& Blanco, C. D. (2003). Public policy implications of changing student attendance patterns. New Directions for Higher Education, 2003(121), 51-68.

[42] Malinena, O.P., Vaisanen, P., \& Savolainena, H. (2012). Teacher education in Finland: A Review of a national effort for preparing teachers for the future. The Curriculum Journal, 23(4), 567-584.

[43] Miller, V. (2001). The new definitions of standards in American education. Washington: The Heritage Foundation.

[44] Mishra, S. (2002) Studying the Process-issues for Organizing Research and Training in Distance Teacher Education. Unpublished Ph.D Thesis, Utkal Univ. Bhubaneshwar.

[45] Mitchell, R.L.G. (2010). Approaching common ground: Defining quality in online education. New Directions for Community Colleges, 2010(150), 89-94.

[46] Moosa, K. (2006). Quality assurance in higher education: Successful approaches for improving quality in colleges and universities. (96-110). In Proceedings of $1^{\text {st }}$ international conference on assessing quality in higher education, 11-13 December, 2006, Lahore-Pakistan.

[47] Motala, S. (2001). Quality and indicators of quality in South African education: a critical appraisal. International Journal of Educational Development, 21, 61-78.

[48] Muylaert, C.J., Junior, V.S., Gallo, P.R., Neto, M.L.R., \& Reis, A.O.A. (2014). Narrative interviews: An Important resource in qualitative research. Rev Esc Enferm USP, 48(2), 184-189.

[49] National Accreditation Council for Teacher Education. (2009). National standards for teacher education programs. Lahore: NACTE.

[50] Nadiri, H., Kandampully, J., \& Hussain, K. (2009). Students' perceptions of service quality in higher education. Total Quality Management, 20(5), 523-535.

[51] OECD (2012). PISA 2012 results: what makes schools successful? Resources, policies and practices vol. IV, OECD Publishing. . Accessed 27.02.16 http://dx.doi.org/10.1787/9789264201156-en. 
[52] Polkinghorne, D.E. (1995). Narrative configuration in qualitative analysis. Qualitative studies in education, 8(2), 5-22.

[53] Ranson, S. (2011). School governance and the mediation of engagement. Educational Management. Administration \& Leadership, 39(4), 398-413.

[54] Riessman, C.K. (2008). Narrative methods for the human sciences. London: Sage.

[55] Sahito, Z. \& Vaisanen, P. (2016). Dimensions of Job satisfaction of Teacher Educators: A Qualitative Study of the Universities of Sindh Province of Pakistan. Journal of Curriculum and Teaching, 5(2), 43-54.

[56] Sahito, Z. \& Vaisanen, P. (2017a). Factors Affecting Job Satisfaction of Teacher Educators: Empirical Evidence from the Universities of Sindh Province of Pakistan. Journal of Teacher Education and Educators, 6(1), 5-30.

[57] Sahito, Z. \& Vaisanen, P. (2017b). The Diagonal Model of Job Satisfaction and Motivation: Extracted from the Logical Comparison of Content and Process Theories. International Journal of Higher Education, 6(3), $209-320$.

[58] Sahito, Z. \& Vaisanen, P. (2017c). Dimensions of Quality in Teacher Education: Perception and Practices of Teacher Educators in the Universities of Sindh, Pakistan. International Journal of Higher Education, 6(5), 44-54.

[59] Sauvé et al. (2005). Influence of the Globalized and Globalizing Sustainable Development Framework on National Policies Related to Environmental Education. Policy Futures in Education, 3(3), 271-283.

[60] Scheerens, J. (2004). The quality of education at beginning of the $21^{\text {st }}$ century, A paper commissioned for the Global Monitoring Report 2005, UNESCO, Paris.

[61] Schillemans, T. (2011). Does horizontal accountability work? Evaluating potential remedies for the accountability deficit of agencies. Administration and Society, 43(4), 387-416.

[62] Sparkes, A.C., \& Smith, B. (2009). Judging the quality of qualitative inquiry: Criteriology and relativism in action. Psychology of Sport and Exercise, 10, 491-497.

[63] Sparkes, A.C., \& Smith, B. (2014). Qualitative research methods in sport, exercise and health from process to product. Oxford, England: Routledge.

[64] Spillane, J. (2001). Standards deviation. How schools misunderstand education policy. Cambridge, MA: Harvard University Press.

[65] Tawil, S., Akkari, A., \& Macedo, B. (2011). Beyond the conceptual maze: the notion of quality in education, Discussion paper 2, UNESCO, Paris.

[66] Thaung, N.N. (2008). Quality indicator. A paper presented in the Capacity Building Workshop on Monitoring and Evaluating Progress in Education in the Pacific in Nadi, FIJI on 27-31 October 2008.

[67] Tikly, L. \& Barrett, A. (2011) Social Justice, Capabilities, and the Quality of Education in Low Income Countries. International Journal of Educational Development, 31(1), 3-14.

[68] Tilak, J.B.G. (2002). Education and Poverty. Journal of Human Development, 3(2), 191-207.

[69] Tracy, S.J. (2010). Qualitative quality: Eight big-tent, criteria for excellent qualitative research. Qualitative Inquiry, 16(10), 837-851.

[70] Tunio, N. A., \& Aziz, S. A. (2012). A study of the effectiveness of teacher training programs in English for secondary and higher secondary schools in district Larkana. Interdisciplinary Journal of Contemporary Research in Business, 6(4) 951-956.

[71] UNESCO. (2005). Education for All: The Quality Imperative. UNESCO Publishers, New York.

[72] UNESCO. (2015b). EFA Global Monitoring Report: Education for All, 2000-2015 (Paris: UNESCO).

[73] UNICEF. (2000). Defining Quality in Education. Working Paper Series. New York: UNICEF.

[74] UNICEF. (2001). The State of the World's children 2001. Published by UNICEF Division of Communication, 3 UN Plaza, New York, NY 10017, USA.

[75] UNICEF. (2012). UNICEF annual report 2012, unite for children. Published by UNICEF Division of Communication, 3 United Nations Plaza, New York, NY 10017, USA.

[76] Van der Bij, T., Geijsel, F.P., \& Ten Dam, G.T.M. (2016). Improving the quality of education through self-evaluation in Dutch secondary schools. Studies in Educational Evaluation, 49, 42-50.

[77] Van Merriënboer, J. J. G., Clark, R. E., \& de Croock, M. B. M. (2002). Blueprints for complex learning: The 4C/ID-model. Educational Technology Research and Development, 50(2), 39-64.

[78] Van Merriënboer, J. \& Kirschner, P. (2007). Ten steps to complex learning: A systematic approach to four-component instructional design. Hillsdale, NJ: Lawrence Erlbaum Associates.

[79] Walker, P. (2008). What do students think they (should) learn at college? Student perceptions of essential learning outcomes. Journal of the Scholarship of Teaching and Learning, 8(1), 45-60.

[80] Wosket, V. (1999). Therapeutic use of self: Counselling practice, research and supervision. London: Routledge.

[81] Yackulic, R. A. \& Noonan, B.W. (2001). Quality indicators for teacher training in Canada. Paper prepared for The 2001 PanCanadian Education Research Agenda Symposium May 22-23, 2001, Lavel University Quebec City.

Zafarullah Sahito is a Ph.D-Student at School of Applied Educational Science and Teacher Education, Philosophical Faculty, University of Eastern Finland, Joensuu. Mr. Sahito is a permanent employee (Assistant Professor) at the department of Education, Sukkur IBA University, Sindh, Pakistan. He has over 18 years of teaching, training and research experience at school and university level in Pakistan.

Pertti Vaisanen is working as a Professor and vice Dean at School of Applied Educational Science and Teacher Education, Philosophical Faculty, University of Eastern Finland, Joensuu. Dr. Vaisanen is a Ph.D supervisor of Mr. Zafarullah Sahito, who is working on the project titled: "A Study of Job Satisfaction and the Motivation of Teacher Educator towards Quality Education". He has over 35 years of teaching, training, administrative and research experience in Finland. 